\title{
A History of the Energy Research and Development Administration
}

March 1982

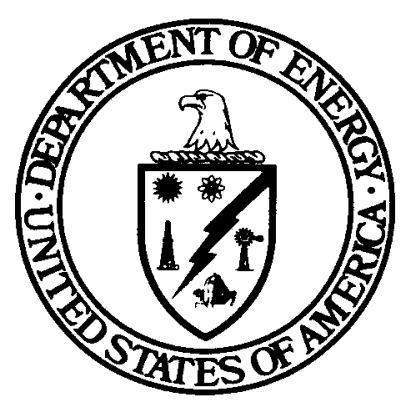

\section{U.S. Department of Energy}

Assistant Secretary, Management and Administration

Office of The Executive Secretary 


\section{DISCLAIMER}

This report was prepared as an account of work sponsored by an agency of the United States Government. Neither the United States Government nor any agency Thereof, nor any of their employees, makes any warranty, express or implied, or assumes any legal liability or responsibility for the accuracy, completeness, or usefulness of any information, apparatus, product, or process disclosed, or represents that its use would not infringe privately owned rights. Reference herein to any specific commercial product, process, or service by trade name, trademark, manufacturer, or otherwise does not necessarily constitute or imply its endorsement, recommendation, or favoring by the United States Government or any agency thereof. The views and opinions of authors expressed herein do not necessarily state or reflect those of the United States Government or any agency thereof. 


\section{DISCLAIMER}

Portions of this document may be illegible in electronic image products. Images are produced from the best available original document. 
DOE/ES- 0001

DE82 009617

\section{A History of the Energy Research and Development Administration}

by:

Alice L. Buck

March 1982

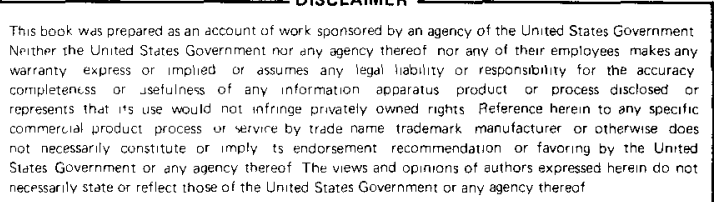

U.S. Department of Energy Assistant Secretary, Management and Administration Office of The Executive Secretary Washington, D.C. 20585 


\section{TABLE OF CONTENTS}

Introduction. . . . . . . . . . . . . . . . 1 Nixon Enerqy Proposals: 1971 - 1974 . . . . . . . . 1 The Energy Reorganization Act of 1974 . . . . . . . . . 2 Organizing the New Agency ................ 2 The National Energy Research, Development, and Demonstration Plans .............. 3 Implementing the Energy Plans: Conservation and Solar . . . . 5 Solar Energy Research Institute . . . . . . . . 6 Geothermal Energy . . . . . . . . . . . . . 7 Wind Energy ...................... 8 Commercialization ................. 8 Nuclear Energy . . . . . . . . . . . . . . . 9 Weapons Custody . . . . . . . . . . . . 10 Field and Laboratory Utilization . . . . . . . . . 10 Breeder Reactor Program . . . . . . . . . . . . 11 Nuclear Waste Disposal . . . . . . . . . . 12 ERDA's 1977 National Plan for Energy

Research, Development and Demonstration. . . ...... 13 Summary .................... . 1 13 Notes ....................... 15 Appendix I - Personnel. . . . . . . . . . . . 18 Appendix II - Chronology . . . . . . . . . . 20 Appendix III - Organization Charts . . . . . . . . 22 
Congress created the Energy Research and Development Administration on October 11, 1974 in response to the Nation's growing need for additional sources of energy. The new agency would coordinate energy programs formerly scattered among many federal agencies, and serve as the focal point for a major effort by the Federal Government to expand energy research and development efforts. New ways to conserve existing supplies as well as the commercial demonstration of new technologies would hopefully be the fruit of the Government's first significant effort to amalgamate energy resource development programs.

Nixon Energy Proposals: $1971-1974$

President Richard Nixon presented his original plan for an energy agency in his first energy message to Congress in June 1971. Citing the "brownouts" which had occurred in recent months, the natural gas shortages, increasing fuel prices, and the lack of an integrated national energy policy, the President proposed that all major energy programs be consolidated in a new Department of Natural Resources. Two years later, in June 1973, he again urged Congress to take action on his energy legislation. Modifying his original proposal in order to place greater emphasis on policy and management, Nixon called for a Department of Energy and Natural Resources, and also asked for two additional agencies to replace the existing Atomic Energy Commission. An Energy Research and Development Administration would be responsible for developing fossil fuels, nuclear power, and potential new forms of energy, while the five-member organization of the Atomic Energy Commission, plus its licensing and regulatory functions, would be transferred to a separate and renamed Nuclear Energy Commission. (1)

The Arab oil embargo of October 16,1973 had an immediate impact on the United States. On November 8 President Nixon sent a message to Congress stating that the energy crisis which had "once seemed a distant threat" was now closing in quickly, and that the Nation "faced the most acute shortages of energy" since World War IJ. The President reiterated his desire for a cabinet-level energy department, but at the same time urged Congress to give priority to the establishment of the Energy Research and Development Administration. Although increasing public concern over the energy crisis lent a certain urgency to the President's proposals, Congress did not act immediately. Months of tension over the Watergate situation as well as numerous debates among congressional committees over the size and shape of the new agencies caused the delay. (2)

In the interim, President Nixon took a number of executive actions to deal with the emergency. On June 29,1973, the responsibilities of the already existing Special Energy Committee and the National Energy Office had been combined and expanded in a new Energy Policy Office under Governor John A. Love of Colorado. On December 4 a Federal Energy Office was established in the Executive Office of the President with control over fuel allocation, rationing, and prices. Under the direction of William Simon, former deputy secretary of the Treasury, the Federal Energy Office advised the President on energy policy issues, and assumed responsibility for implementing "Project Independence," Nixon's plan for achieving national energy self-sufficiency by 1980 .

On January 23,1974, Nixon again appealed to Congress to take action on his legislative proposals. He called for the establishment of a Federal Energy 
Administration to carry on the work of the Federal Energy Office on a continuing basis, and for an Energy Research and Development Administration and a Department of Fnergy and Natural Resources to provide a balanced energy program for the future. He urged that priority be given to the first two agencies. Nixon accurately predicted that when a cabinet-level department was eventually established, it would incorporate the functions of the other two agencies. (3)

The President's efforts to have his energy legislation passed continued into the spring with little success. Finally, on May 7, he signed into law the act creating the Federal Fnergy Administration (FEA) as a new and independent agency to replace the Federal Energy Office. With his resignation in August of 1974, however, it remained for Nixon's successors to sign into law the final versions of his original energy proposals.

The Energy Reorganization Act of 1974

On October 11, President Gerald R. Ford signed the Energy Reorganization Act of 1974. The Act abolished the Atomic Fnergy Commission and created three new federal entities: the Energy Research and Development Administration (ERDA), the Nuclear Regulatory Conmission (NRC), and an Energy Resources Council composed of the Secretaries of State and Interior, the administrators of ERDA and FFA, and the director of the Office of Management and Budget.

The .Energy Research and Development Administration brought together for the first time the major programs of research and development for all forms of energy. Along with the programs, a total of 7,222 employees made the transfer to the new agency, which for Fiscal Year 1975 would have an estimated budget of $\$ 3.6$ billion. The Atomic Energy Commission contributed personnel, budget, and programs concerned with nuclear reactors, fusion research, uranium enrichment, and basic scientific research, along with its vast network of offices, national laboratories and nuclear weapons research and production facilities. A variety of energy programs came from other federal agencies. From the Department of the Interior came the Office of Coal Research and the non-regulatory functions of the Bureau of Mines, including the energy centers, the synthane plant, the coal liquefaction and gasification programs, and activities related to underground electric power transmission. The National Science Foundation contributed its solar heating and cooling and geothermal power development projects, while the Fnvironmental Protection Agency transferred its research, development, and demonstration programs relating to advanced automotive propulsion. Although these diverse elements included some of the Nation's finest talent in research and development, the new energy administration would take more than a year to meld them into a smoothly functioning agency. (4)

\section{Organizing the New Agency}

President Ford selected Robert C. Seamans, Jr., president of the National Academy of Engineering, as the first head of the Energy Research and Development Administration. A former Secretary of the Air Force and deputy administrator of the National Aeronautics and Space Administration, Seamans took office on December 30,1974 , a few weeks prior to the formal establishment of the agency on January 19, 1975. Perhaps to dispel the idea that the Energy Research and Development Administration was simply a continuation of the old Atomic Energy Commission, Seamans established his headquarters in downtown washington, twenty-five miles 
southeast of the former Commission headquarters in Germantown, Maryland, and conveniently close to the White House and Congress. (5)

Although the deputy administrator and six assistant administrators were presidential appointments, Seamans was influencial in the selection for each position. Robert A. Fri, a former deputy administrator of the Environmental Protection Agency, became the deputy administrator of ERDA, and worked closely with Seamans in developing a closely integrated organization. Innovative progra$\mathrm{ms}$, such as the regular monthly meeting of all assistant administrators to review key budget and planning operations, provided program continuity, while weekly staff meetings enabled seamans to keep in close contact with key personnel.

In addition to Seamans and Fri, six assistant administrators headed the major programs for fossil, nuclear, solar, geothermal and advanced energy systems, conservation, environment and safety, and national security. The fact that the agency had a total of eight presidential. appointments reflected the desire of Congress to establish an adequate balance among the different energy systems. The fuel programs, fossil, nuclear, solar, and geothermal and advanced energy systems, received the major portion of the research budget, with lesser amounts allocated to energy conservation. Conservation was not entirely a matter of research and development and had been added as a major program almost as an afterthought.

With 5 percent of the world's population using 30 percent of the available energy resources, Congress recognized that the future held enormous problems unless the Nation developed a strategy for conservation. (6)

Seamans selected four additional assistant administrators to fill key staff positions in Planning and Analysis, Administration, Laboratory and Field Coordination, and International Affairs. Yet long before Seamans organized the last office or filled the last position he found himself involved in carrying out two urgent congressional mandates: the first involved the creation of a national plan for energy research, development, and demonstration, while the second concerned the custody of the weapons program inherited from the Atomic Energy Commission. (7)

The National Energy Research, Development and Demonstration Plans

Each of the five major energy bills passed by the 93rd Congress had an impact on the Energy Research and Development Administration. While the first, the Energy Reorganization Act of 1974, brought the Agency into existence, the second, the Federal Nonnuclear Act of 1974, included a requirement that the Administrator present to Congress, not later than June 30 of each year, a comprehensive plan for energy research, development, and demonstration. The remaining energy bills, the Solar Heating and Cooling Act of 1974, the Geothermal Energy Research, Development and Demonstration Act of 1974, and the Solar Energy Research, Development, and Demonstration Act of 1974, contained injunctions to the Administrator of ERDA to initiate and conduct research and related activities which would effectively use solar and geothermal energy. The research would be coordinated with other federal agencies having unique technological capabilities. (8)

Seamans submitted the first national energy plan, "Creating Energy Choices for the Future," to the President and the Congress on June 28, 1975. Developed in consultation with other government agencies and representatives of the private sector, the two volume report outlined short-term (to 1985), mid-term (1985-2000), and long-term (after 2000) programs for developing energy resources. The plan had 
received a final review earlier in the month when Seamans presented it to the Energy Resources Council during a two-day meeting at Camp David. (Seamans' weekly meetings with the Energy Resources Council served to coordinate ERDA's activities with the larger energy policy issues of the Government.) (9) Citing the fact that oil and gas imports totaled 20 percent of the total U.S. domestic energy consumption in 1974, the plan called for a shift to new primary forms of energv, and outlined five changes that should be made rapidly and simultaneously in the nature and scope of energy research, development and demonstration programs.

To provide new energy choices for the future, it would be necessary:

1. To overcome the technical problems (primarily operational reliability and environmental impact) preventing an expansion of current major energy sources such as coal plants and nuclear reactors;

2. To emphasize energy conservation in automotive transportation, buildings and industrial processes;

3. To accelerate the capability to extract gaseous and liquid fuels from coal and shale;

4. To include electricity generated by solar power as a high priority development, along with fusion and the breeder reactor; and

5. To concentrate on under-used technologies capable of being rapidly developed for the mid-term and beyond, such as solar heating and cooling and the use of geothermal power.

In summary, ERDA's first national energy plan called for an early demonstration of the technical feasibility of new energy systems with built-in environmental and safety controls. The Federal Government should provide overall leadership and undertake only those efforts that industry could not initiate. As a technology approached the stage of commercialization, industry would assume the initiative.

A sense of urgency ran through the Seaman's report: the effort was formidable; the margin for failure was small; the risks for the Nation were great; the schedule would have to be adhered to if results were to be achieved and overall goals fulfilled. The near-term results would require an immediate expansion of existing energy resources and the implementation of conservation technologies, while mid-term results would require the establishment of a synthetic fuels industry and continued growth in electrification. Iong-term results would require the development of technologies to unlock the potential of essentially inexhaustible sources of energy such as breeder reactors, fusion and solar electric (wind, thermal, photovoltaics and ocean thermal). Seamans believed that a sixty-year lead time was no longer possible as in past energy transitions, and that in the current situation a transition to new forms of energy would have to be made in half the time and in a far more complex world.

The title of the 1975 energy plan, "Creating Energy Choices for the Future," reflected Seaman's determination to commit the Energy Research and Development Administration to an experimental approach. Rather than follow a rigid plan that excluded options, he preferred a policy of exploring all energy options that offered potential in order to have choices for the future. According to the ERDA Administrator, the current energy crisis was a direct result of having no good choices. Following the publication of the 1975 energy plan, ERDA sponsored a series of public meetings in major cities across the country to encourage public discussion and increase understanding of both national and regional energy issues. 
Many of the misconceptions about the energy crisis were brought to light and clarified through these meetings. Expectant mothers worried about the fate of their unborn children if they walked near nuclear reactor plants. Other citizens voiced their fears that huge oil companies might be holding up foreign oil supplies in order to raise prices, while still others expressed concern over the unnecessary development of high energy technology. (10)

Seamans submitted a revised edition of the national energy plan, "Creating Energy Choices for the Future," on April 15, 1976. While the basic goals and strategy remained much the same, conservation, or energy efficiency, was singled out for increased attention and ranked with several supply technologies as being of the highest national priority. The increased emphasis on conservation would help provide time to develop new energy sources to replace dwindling supplies of oil and gas. The 1976 plan also gave additional emphasis to the role of industry in the development of new energy technologies, and added a short-term planning category which focused attention on opportunities for technology development having effect within five years. Federal programs to assist industry in accelerating the commercialization of near-term technologies were a key element in the plan. (11)

Implementing the Energy Plans: Conservation and Solar

Conservation was considered one of the most significant of the near-term solutions to the energy problems of the Nation. In its early months the Energy Research and Development Administration began working on a two-part strategy for informing the American public of ways to conserve energy, and for encouraging industry to develop greater efficiency in heating and cooling systems, and in machinery, home appliances, and automotive transportation. Among the early programs sponsored by ERDA were those to improve energy storage systems and to develop batteries for electric automobiles. (Two years later, as his last official act as Administrator, seamans rode in an ERDA electric car in President Carter's inaugural parade.) (12)

Although conservation was obviously one of the most immediate options to pursue, far more popular was the idea of using the sun to solve all energy problems. Public enthusiasm for solar energy as a potential solution to the energy crisis was reflected in the fact that three of the five major bills passed by the 93rd Congress in 1974 were concerned with solar and geothermal energy, and by the fact that that, for the first time, a major government agency had a separate division for solar energy. Solar energy was by no means a new technology in the United States. More than 100,000 solar hot water heaters had been installed in homes in California and Florida in the early part of the century. The market began to decline in the 1940's, however, because of the competition of low-cost systems using fossil fuels. Then the 1970's brought rising fuel prices and a renewed interest in solar energy. It soon emerged as one of the leading candidates for solving the energy crisis. (13)

In addition to the yearly energy research, development and demonstration plan presented to the President and the Congress, the ERDA Administrator was required to submit a detailed report defining the agency's overall solar program. Assistant Administrator for Solar, Geothermal and Advanced Energy Systems, John Teem, explained to the House Comittee on Science and Technology that ERDA's goal was to develop and demonstrate commercially attractive and envirommentally 
acceptable applications of solar energy at the earliest feasible time. His office would propose four major program units to achieve this goal: (1) direct thermal applications, (2) solar electric applications, (3) fuels from biomass, and (4) technology support and utilization. Pilot scale facilities and demonstration projects would provide a basis for commercialization decisions. By the year 2020, solar energy could supply as much as 25 percent of the Nation's energy needs from domestic resources if costs of collecting and utilizing solar energy could be reduced substantially.

In his July 16, 1975 presentation to the House committee, Teem also said that he believed ERDA was launching an aggressive solar program but instant results would be very difficult to achieve. The critical phase would occur in the next few years as the data and judgment were developed to establish credible priorities. The ERDA National Program for Solar Heating and Cooling was published the following October and called for the demonstration of solar heating by the end of 1977, and combined heating and cooling by the end of 1979. The Government's role would be to stimulate industry and potential users of equipment, and to assist industry with development and demonstration programs which hopefully would lead to the widespread use of solar energy. (14)

During the first year of operation, the Energy Research and Development Administration designated approximately four million dollars for commercial projects demonstrating solar water and space heating in various regions of the country. On April 5, 1976 Robert L. Hirsh, who replaced Teem, announced that buildings in twenty-two states and the Virgin Islands had been selected for the installation of solar heating and cooling systems to demonstrate that solar energy was practical for heating and cooling buildings such as schools, hotels, fire stations, factories and offices. Six months later a second phase of the demonstration program detailed plans to provide government support for thirty-five to fifty new solar heating and cooling systems in commercial buildings on a costshared basis. Technical management support would be provided by the NASA Marshall Space Flight Center in Alabama. (15)

Construction began in early 1976 on a five-megawatt thermal solar test facility at ERDA's Sandia Laboratories in Albuquerque, New Mexico. Even before completion, the facility became the largest operational solar installation in the world, and in the next few years was able to assist in resolving many of the technical problems involved in the design and development of an even larger pilot plant constructed in the Mojave Desert near Barstow, California. The ten-megawatt Barstow plant, scheduled to be in operation in the $1980 \mathrm{~s}$, represented a first step toward the potential development of power plants in the 100-megawatt range which could supplement the use of fossil and nuclear fuels in utility systems. (16)

Solar Energy Research Institute

Under the Energy Reorganization Act and the Solar Energy Research Development and Demonstration Act of 1974, Congress authorized the construction of a Solar Energy Research Institute to support ERDA's solar program and to aid in establishing an industrial base for solar energy. ERDA immediately requested the National Academy of Sciences to provide assistance in defining the scope and structure of such an institute. 
A National Academy committee, chaired by Richard L. Garwin of the research division of IBM, strongly recommended the establishment of the institute, and agreed that the congressional mandate reflected not only a public assessment of the importance of solar energy, but a congressional desire for activity in solar energy comparable to the Nation's twenty-five year support of nuclear energy. The plan outlined by the comittee called for an organization which could serve as a center of expertise capable of "harnessing science, technology and analysis in the service of the Nation."

There was considerable public interest in the location of the Solar Energy Research Institute, or SERI as the facility was soon called. In March of 1977 , after two years of highly competitive bidding, Acting Administrator Robert Fri selected Golden, Colorado as the initial site for SERI and named the Mid-west Research Institute as the managing contractor. Additional regional centers would be established as needed. The concept of having regional centers represented a departure from the recommendation of the National Academy of Sciences that a single research center be set up with only a few small specialized field stations. (17)

Paul Rappaport, a physicist from the research division of the David Sarnoff laboratory at Princeton, headed the Institute's initial staff of seventy-five professionals who soon became involved in evaluating all aspects of solar technology, including direct solar conversion (photovoltaics), solar heating and cooling, solar thermal power generation, wind, ocean thermal conversion, and biomass conversion. The Institute officially began operating in July 1977, just a few months before becoming part of the new Department of Energy.

\section{Geothermal Energy}

In response to the requirements of the Geothermal Research, Development and Demonstration Act of 1974, Assistant Administrator Teem and his staff made an early assessment of the problems involved in developing geothermal energy as a viable option for the future. An October 1975 report indicated that in spite of the Nation's enormous geothermal resource base, numerous obstacles prevented a rapid development of the industry. Detailed resources were not available and there was insufficient knowledge of possible environmental inpacts or of the control technology requirement that might be needed for rapid industrial growth. But in spite of the difficulties outlined in the report, the Energy Research and Development Administration proposed a geothermal energy program that called for federal assistance in areas of high technical risk, information dissemination, and loan guarantees to reduce financial risk. (18)

ERDA undertook a variety of geothermal projects in cooperation with other federal, state, and local agencies. One of the earliest projects involved drilling for hot water in areas where ground waters had infiltrated formations of heated rock by a process called hydrothermal convection. In February 1975, in a project undertaken jointly by ERDA, the State of Idaho, and the Raft River Corporation, drillers in southern Idaho successful.ly tapped a hot water well which produced at 4650 feet a water flow of about 1500 gallons per minute heated to 280 degrees Fahrenheit.

Other geothermal projects involved research and development efforts on hot ary rock systems for the purpose of recovering useful heat. An experimental 
ten-megawatt geothermal test loop facility, dedicated at Niland, California in June 1976, was designed to test converting energy from deep beneath the earth to useful electricity. Heat was extracted from hot salty brines and the cooled fluid was then reinjected into the ground. In addition to funding the project, ERDA also supplied technical support and research through the Iawrence Livermore Laboratory in California. The joint project between the Government and the San Diego Gas and Electric Company exemplified the type of government-industry cooperation that ERDA hoped would create new energy choices for the future. (19)

\section{Wind Energy}

In the 1970's wind energy began to receive serious consideration in the United State as a possible source of electricity for comercial use. Although windmills had been used for generations on farms across the Nation, the largest windmill ever built and operated in the United States for commercial purposes was the Smith-Putman wind turbine machine constructed near Rutland, Vermont in October 1941. The 1.25 megawatt windmill supplied power to the electrical network of the Central Vermont Public Service Company intermittently from October 1941 until one of the rotor blades broke in March 1945. The machine was never repaired and wind power as a source of energy received little attention until the early 1970's.

The wind energy program inherited by the Energy Research and Development Administration was originally a part of the Federal Energy Administration's Project Independence Solar Energy Plan and involved a number of federal agencies. The National Aeronautics and Space Administration continued to direct the development of large-scale experimental systems, while the Department of Agriculture investigated smaller units for farm and rural use. ERDA's first prototype wind power system was completed in 1975. Located at Sandusky, Ohio, the 125-foot blade, 100 kilowatt wind generator was designed and built in cooperation with NASA to test components and gather data on wind turbine systems. The following year ERDA selected Clayton, New Mexico as the site for a new 200 kilowatt version of the Sandusky machine. These modern windmills would eventually determine the economics of wind energy systems interconnected with conventional power plants. (20)

Unlike many other government agencies which both develop and use new technology, the Energy Research and Development Administration had the responsibility for ensuring that appropriate technology development was carried out but with the expectation that it would be transferred to industry for use. Therefore one of ERDA's primary concerns was to develop technologies which would be acceptable in the marketplace. The absence of a comprehensive national energy policy, however, made the process of commercialization difficult to implement. (21)

\section{Commercialization}

In January 1976, in order that ERDA might assist more effectively in the process of moving new energy technologies into the marketplace, seamans established an Office of Commercialization. As outlined in the annual ERDA energy plans, industry was expected to take the initiative in the commercialization process while the Federal Government played a supportive role by identifying major problems and implementing steps to overcome them. The most significant task given the office of Commercialization, however, was that of coordinating the planning 
for a synthetic fuels commercial demonstration program that would produce oil and gas from coal, oil shale and solid wastes. William T. McCormick, who had been in charge of the synfuels program for ERDA since November, continued to direct the program as head of the new Office of Commercialization.

McCormick had already spent many months working in the area of synthetic fuels. In the spring and summer of 1975, while chief of the Science and Energy Technology Board in the Office of Management and Budget, he had been head of a presidential task force charged with preparing a detailed strategy for producing a million barrels of synthetic fuel a day within ten years. The final report, "Recommendations for a Synthetic Fuels cormercialization Program," contained a two-phase proposal for producing a million barrels of synthetic fuel a day by 1985, and incorporated federal incentives such as loan guarantees, price supports, and construction grants. The initial phase would include two shale oil plants, three high-B'U gas plants, and five waste conversion plants. The task force report, which formed the basis for President Ford's synfuels legislative proposals, contained a recormendation that the Energy Research and Development Administration carry out the proposed program. (22)

In spite of the support of the Ford administration, however, Congress deleted a $\$ 6$ billion synthetic fuels loan guarantee provision in the ERDA authorization bill for 1976. As a result the office of Commercialization had a very short life. In November 1976, part of the staff was reassigned to the Office of the Assistant Administrator for Fossil Energy to assist with demonstration programs in fossil fuel, while other staff members went to the Office of Planning, Analysis and Evaluation. "Evaluation" had been added to the "Planning and Analysis" functions the previous July when the office had been given the additional responsibility of evaluating the success of various energy programs.

One of the demonstration programs that had come to EPDA with the Office of Coal Research was the "Coalcon" (Clean Boiler Fuel Demonstration Plant Project) project to demonstrate the commercial feasibility of converting high sulfur coal into liquid and gaseous fuels by a process called hydro-carbonization. On November 19, 1975, Seamans announced that a 2000 acre site in southwestern Illinois had been selected from among sixteen possible locations for the plant scheduled for completion in $1980 .(23)$

A number of other organizational changes took place in July 1976. Eric Willis, who had been serving as director of the Division of Geothermal Energy, became the agency's eleventh assistant administrator when several offices were combined to form an Office of Institutional Relations. In addition, an office of Programs Integration was established under David Israel, Seamans' technical assistant. Through these two new offices seamans sought a more effective relationship with institutions involved in research and development programs and with prospective commercial users or producers of new technology. (24)

\section{Nuclear Energy}

One of the major program areas, nuclear energy, confronted the FRDA administrator with a disproportionate share of problems during the first year of the agency's existence, a fact not totally unexpected since the larger portion of ERDA programs, personnel, and budget had come from the Atomic Energy Commission. Four of the issues requiring early decisions were the custody of the nuclear weapon 
program, the use of the national laboratories, the future of the liquid metal fast breeder reactor, and the handling and storage of nuclear wastes. Seamans organized special groups to study the possible course of action to be taken in each area.

\section{Weapons Custody}

The Reorganization Act of 1974 required the Administrator of ERDA and the Secretary of Defense to review the feasibility of transferring the military functions formerly vested in the Atomic Energy Conmission to the Department of Defense or to other federal agencies. The possible transfer of these functions, which included not only weapon development and the control of Restricted Data, but also certain non-defense related programs such as naval reactors, space nuclear systems, military power reactors, and the production of special nuclear materials, reflected continuing congressional concern over the issue of civilian control of the military atom.

In January 1976, following a year of study, Seamans concluded that it would be detrimental to a strong nuclear weapon program to split the management and funding responsibilities between different agencies. He recommended instead that the nuclear weapon program and complex be retained within ERDA, but have a budget of its own, separate from the budget for energy programs. The Assistant Administrator for National security would be responsible for seeing that the weapon program received priority in the use of laboratories and production facilities, while non-weapon defense-related programs would be under the direction of the Assistant Administrator for Nuclear Energy. The unique capability of the weapon research laboratories to perform significant nonnuclear research in the energy development field was another factor in the final decision to leave the division of military application and the associated nuclear activities within the Energy Research and Development Administration. (25)

\section{The Field and Laboratory Utilization Study}

During his first year as ERDA Administrator, Seamans faced the task of formulating a plan for coordinating and administering the large contractoroperated, governmentowned laboratories and field operations Offices that came from the Atomic Energy Commission, and the few small, highly specialized, governmentstaffed Energy Research Centers from the Bureau of Mines. In July 1975, Seamans asked Michael Yarymovych, Assistant Administrator for Iaboratory and Field Coordination, to establish a special study group to recormend ways to make the optimum use of ERDA's field and laboratory resources. The field facilities consisted of some fifty-five plants and labs, staffed by about 91,000 contractor personnel. Major contractors included universities, university consortia, nonprofit organizations, and private industry. In comparison, the six Energy Research Centers employed only 784 federal employees and dealt almost entirely with fossil energy research and development. Each of the eight operations offices administered the operating contracts for the ERDA facilities in its own region. The total field complement was 4,258, including area offices and headquarters site representatives.

The number of Energy Research Centers was reduced from six to five on September 10, 1975 when the San Francisco Center was combined with the San Francisco Operations Office. Under the direction of Robert D. Thorne, formerly 
with the Atomic Energy Cormission, and later Acting Assistant Administrator for Nuclear Energy, the San Francisco Operations Office was able to take some line responsibility, particularly for the geothermal programs.

Seamans had hoped that a number of field offices could be set up around the country so that certain projects could be handled locally rather than through headquarters. This was one of the recommendations made in the Field and Laboratory Utilization (FLU) Study Group report of December 1975. After several months of meetings and visits to field offices, the group concluded that the operations offices should not only procure, but also manage projects in the engineering development and demonstration categories, while the laboratories and Energy Research Centers should perform work in the research and technology development categories in assigned areas of responsibility. After initial planning with headquarters, the laboratories and energy centers should be given considerable freedom to carry out their missions. In addition, the study group proposed that ERDA centers be set up in appropriate regional cities with headquarters at existing Operations Offices, and satellite offices established as needed.

Many of the recommendations of the Field and Laboratory study were contained in an Administrator's management goals memorandum of January 23, 1976, and in staff work plans introduced a year later by Yarymovych, now Assistant Administrator for Field Operations. Seamans had little success in implementing recommendations for establishing field offices in major cities, however. Perhaps the reluctance of the Office of Management and Budget to increase the size of the ERDA field operations was related to the serious consideration being given at the time to the creation of a Department of Energy. (26)

Breeder Reactor Program

A major civilian reactor program inherited by ERDA from the Atomic Energy Cormission was the development of the liquid metal fast breeder reactor (IMFBR) . The Nation's first large-scale government-industry fast-breeder project involved a demonstration plant in Oak Ridge, Tennessee - the Clinch River Breeder Reactor (CRBR) - and a test reactor facility in Richland, Washington - the Fast Flux Test Facility (FFTF).

As a result of the Federal Court of Appeals' Calvert Cliffs decision of July 23, 1971 against the Atomic Energy Conmission, an environmental impact statement had to be filed before work could be started on the breeder reactor project. Rather than file a brief with the courts in its closing days as an agency, the AEC passed on to ERDA a 4500 page draft environmental impact statement. A review committee, headed by Robert Fri, determined that the potential need for additional energy in the future was sufficient to justify going ahead with the research and development on the breeder reactor. The environmental impact statement was then filed and the court's restraining order was removed.

Clinch River was to be a major step in the transition from the Government's twenty-five year development of liquid metal fast breeder reactor technology to large-scale demonstration of the fast breeder concept. In May 1976 ERDA assumed direct responsibility for the project in partnership with the Commonwealth Edison Company and the Tennessee Valley Authority. The $700 \mathrm{U} . \mathrm{S}$. electric systems represented by the Project Management Corporation, which had managed Clinch River since 
1972, would continue to monitor the project, disburse utility funds, and provide liaison with the utility industry. The goal was to demonstrate the technical and economic feasibility of the liquid metal fast breeder reactor as a practical source of power with emphasis on safety, reliability, and environmental acceptability. Major construction was scheduled to begin in 1978 with an initial startup targeted for 1984. (27)

\section{Nuclear Waste Disposal}

One of the most difficult problems ERDA inherited from the Atomic Energy Commission was finding a solution to the nuclear waste storage problem. Following the recommendations of a special task force assigned to review all aspects of the nuclear fuel cycle, Seamans hastened to centralize headquarters waste management activities and transferred all operational responsibilities in both civilian and defense areas to an expanded Division of Nuclear Fuel Cycle and Production. Environmental control oversight of the program was assigned to a new Division of Environmental Control Technology. The reorganization enabled the ERDA headquarters staff to begin to develop a coherent policy on waste management.

In the spring of 1976, at the request of the Joint Committee on Atomic Energy, the staff conducted a comprehensive study on the technical alternatives available in the waste disposal program. A five-volume report presented detailed descriptions of the options available for treating wastes from power reactors, reprocessing plants, and fuel fabricating facilities, comprising what is known as "the backend of the fuel cycle." At the same time ERDA developed a new concept of placing "multiple barriers" between high-level wastes and the environment. This would be achieved by converting liquid waste into a stable solid form which could then be sealed in a high-integrity container and transported to a terminal repository in a deep, stable geologic formation. Acceptable sites would be simultaneously investigated in a number of geographic locations and geologic formations. The idea of multiple sites for storage would avoid the charge that ny ne state was being singled out as a "national waste dump." The ERDA budget .or fiscal year 1977 reflected a large increase in funds for the waste disposal program, and plans were made for pursuing a variety of technological solutions to waste disposal.

President Ford singled out a number of issues for special study, in the summer of 1976, when he requested ERDA's Deputy Administrator, Robert Fri, to organize an interagency task force to review U.S. nuclear policy. The President's July 19th directive called for a comprehensive review and examination of issues involved in "closing" the nuclear fuel cycle. Included were nuclear exports and safeguards, the reprocessing of spent fuel from commercial reactors, and the storage of nuclear wastes. Both the President's October 28 statement on nuclear policy, and his final energy message to Congress in January 1977, reflected recommendations made in the Fri task force report. For nearly a decade, Ford declared in the October statement, the U.S. had not had a monopoly on nuclear technology. Action to control proliferation, therefore, should be an international cooperative effort, requiring an acceleration of U.S. diplomatic initiatives to control the spread of plutonium separating technologies.

On January 7th, the President urged Congress to provide authority for the Energy Research and Development Administration to enter into cooperative agreements with U.S. firms wishing to build and own uranium enrichment plants. He also 
reminded Congress of his 1977 budget proposal for a four-fold increase in funding for the nuclear waste management program, and his directive to ERDA to demonstrate all components of waste management technology by 1978 and to provide a complete repository for such wastes by 1985 .

ERDA plans for pursuing technological solutions to waste disposal had to be cancelled following an announcement by President Jimmy Carter, on April 7, 1977, that the United States would defer indefinitely all reprocessing and recycling of spent fuel from civilian power reactors. Alternate fuel cycles and processes were to be evaluated. The new President also announced that he intended to defer indefinitely the commercialization of the liquid metal fast breeder reactor project. Carter's decisions, based on a desire to reduce the proliferation of nuclear weapons, represented a major shift in U.S. nuclear energy policy. With only a few months of its existence as an agency remaining, ERDA had little opportunity to do more than begin the extensive reorganization of the waste disposal program required by the new policy. (28)

ERDA's 1977 National Plan for Energy Research, Development and Demonstration

Acting Administrator Robert Fri, who had assumed the ERDA helm when Seamans resigned in January 1977, presented the agency's third and final energy research, development and demonstration plan, ERDA-77-1, on June 23. Fri informed the President that the ERDA plan was in accord with the President's National Energy Plan submitted to Congress on April 20, and would provide the basis for the technological changes needed to weather the difficult period of transition from dependence on limited oil and natural gas to inexhaustible or renewable sources of energy. Conservation, or increasing the efficiency of energy use, was again stressed as having the greatest immediate impact on the Nation's energy system between 1977 and the year 2000. A successful conservation program would require voluntary participation by the public, economic incentives, regulatory actions and the development of more efficient technologies to use and produce energy. (29)

There may or may not have been some significance to the fact that Fri dropped Seaman's title, "Creating Energy Choices for the Future." Whatever the reason, ERDA-77 sounded a somewhat more somber note than the two preceding reports. The urgency and expectancy of the earlier reports were replaced by a resigned recognition that despite positive efforts by the Federal Government and by state governments, industry, and the American public to conserve energy and to increase domestic energy supplies, the Nation was more reliant than ever on the least plentiful domestic energy resources, petroleum and natural gas.

The Fri report concluded, somewhat more optimistically, that the research and development activities of the Energy Research and Development Administration, if combined with the efforts of other federal agencies, could provide the basis for the technology changes needed to meet the energy needs of the future. (30)

\section{$\underline{\text { Summary }}$}

The Energy Research and Development Administration was essentially a transitional agency, established during a time when energy shortages and rising costs forced the Nation to grapple with the problem of bringing together its scattered energy programs. Three years was a short period of time in which to show visible 
progress in solving the Nation's energy problems, brought so clearly to the forefront by the Arab oil embargo of 1973. There was no easy road to instant commercialization of new technologies. Research and development required years of testing, billions of dollars in new capital and the construction of highly complex facilities.

ERDA, nevertheless, made significant progress in developing national energy research and development plans, in mobilizing talent, and in coordinating the diverse energy activities formerly scattered among many federal agencies. The staff worked closely with all segments of industry, with the academic conmunity, with foundations, with non-profit corporations, and with foreign countries. Bilateral agreements were made with nations all over the world as well as with a number of international organizations such as Euratom and the International Energy Agency. Although the national goal of early commercialization of synthetic fuels was not realized, by the time ERDA was absorbed into the Department of Energy in the fall of 1977 programs were well underway for the near-term demonstration of more efficient ways to recover and use coal, oil and shale, and a number of pilot plants had been constructed or were in progress.

The creation of the Energy Research and Development Administration in January 1975 represented an important step by the Ford Administration in a reorganization trend that began with the establishment of the Federal Energy Office by President Nixon in 1973, and climaxed with the creation of a cabinet level Department of Energy in the fall of 1977 by President Carter. The first two agencies, the FEO and its successor the Federal Energy Administration, were given responsibility for both the administration and the regulation of energy. (31) ERDA's mandate on the other hand clearly excluded regulation, and called for a concentration on the research and development of new energy technologies which might lead to commercialization. The functions of the three agencies found a merging point in the Department of Energy. Federal energy policy and programs, and the vast number of significant energy projects and technologies originated and coordinated by the Energy Research and Development Administration, would now be conducted in a single agency and in an arena of highest national priority. (32)

The final ERDA national energy plan, in consonance with the President's overall energy plan, called for a strong basis from which to weather the transition from limited supplies to renewable or inexhaustible sources of energy. The hope of the Carter Administration was that the larger arena of a cabinet level department would provide that needed basis. 


\section{FOOTNOTES}

1. Richard M. Nixon, "Statement," June 29, 1973, as reprinted in Executive Energy Documents, published by the Senate Committee on Energy and Natural Resources, July, 1978, 49-55, 11, (Hereafter cited as SCEN Energy Documents).

2. Neil DeMarchi, "Fnergy Policy Under Nixon: Mainly Putting Out Fires," in Crauford D. Goodwin, Editor, Energy Policy in Perspective: Today's Problems, Yesterday's Solutions (The Brookings Institution, 1980, 435; Jack M. Holl, "The United States Department of Energy: A History," Institutional Origins of the Department of Energy, Energy History Series, Vol. 1, No. 4, Sept. 1981. (Hereafter cited as IODE, History Series); Richard M. Nixon, "Message to the Congress," Nov. 8, 1973, SCEN, Energy Documents, 95-98.

3. Richard M. Nixon, "Proposals to Deal with the Energy Crisis," Jan. 23, 1974, SCEN, Energy Documents, 119, 128.

4. Gerald R. Ford, "Statement of the President on Signing the Energy Reorganization Act of 1974," Oct. 11, 1974, SCEN, Energy Documents, 163-68;"Fact Sheet: ERDA Organization," no date.

5. "Dr. Seamans Sworn in as Administrator of ERDA," AEC 262, Dec. 30, 1974; "Activation of the Energy Research and Development Administration," ERDA 1, Jan. $20,1975$.

6. "Meeting of Dr. Robert C. Seamans with AFC Staff, Germantown, Maryland," Jan. 7, 1975.

7. "All Six Posts Filled," ERDA News, Vol. 1, No. 1, Dec. 5, 1975; "Seamans Announces Appointment of Assistant Administrator for Administration," ERDA 75-6, Jan. 31, 1975; "Seamans Announces Appointment of ERDA Controller," ERDA 75-5, Jan. 31, 1975; "Seamans Names General Counsel," ERDA 75-9, Feb. 3, 1975; "Assistant Administrator for International Affairs Named by Dr. Robert C. Seamans, Jr.," ERDA 75-16, Feb. 14, 1975; "ERDA Assistant Administrator for Planning and Analysis Named," ERDA 75-24, Feb. 27, 1975; "Appointment of Roger W. A. LeGassie as Assistant Administrator for Planning and Analysis," ERDA 33, March 11, 1975; "Dr. Yarymovych Heads ERDA's Laboratory and Field Coordination," ERDA 75-48, April 10, 1975; "The White House," Press Release, June $6,1975$.

8. Section 6(a), Federal Nonnuclear Energy Research and Development Act of 1974, Public Iaw 93-577, Dec. 31, 1974.

9. Rogers C.B. Morton to Members of the Energy Resources Council, Oct. 16, 1974.

10. ERDA-48, "A National Plan for Energy Research, Development and Demonstration: Creating Energy Choices for the Future," Vol. 1, June 28, 1975, 5-8; "ERDA Schedules Public Meetings on National Energy Research and Development Plan," ERDA 75-191, Sep. 22, 1975; "National Energy Research Development and Demonstration Plan outlines Priorities and Calls for Major Changes," ERDA 75-103, June 30, 1975; "Remarks by Dr. Robert C. Seamans to the National Association of Science Writers," ERDA S-5-75, April 29, 1975. 
11. ERDA 76-1, "A National Plan for Energy Research, Development and Demonstration: Creating Energy Choices for the Future," Vol 1, April 15, 1976; "Conservation Stressed in Updated National Energy Research and Development Plan," ERDA 76-103, April 19, 1976.

12. "ERDA Administrator Notes Major Steps in Energy Research and Development During Agency's First Year," FRDA 76-5, Jan. 18, 1976; "ERDA is Ready to Get It's Energy Projects Rolling," Albuquerque Tribune, Jan. 16, 1976, 9-10.

13. ERDA-49, "National Solar Fnergy Research, Development, and Demonstration Report," June 1975; ERDA-23A, "National Program for Solar Heating and Cooling," Oct. 1975; Ethan B. Kapstein, "A Solar Energy Heyday," DOE Energy History Report, Dec. 1979, 1.

14. Oversight Hearings before the Subcommittee on Energy Research, Development, and Demonstration, House Committee on Science and Technology, June 16, 1975, 14,38 .

15. "ERDA Selects 34 Solar Demonstration Projects," ERDA 76-93, April 5, 1976; "ERDA Seeks Proposals for Solar Heating and Cooling Commercial Projects," ERDA 76-331, Oct. 29, 1976.

16. "ERDA Announces Site, Architect-Engineer for 5-Megawatt Solar Experimental Facility." ERDA 75-142, July 28, 1975; "Largest Solar Facility Passes Test in New Mexico," ERDA 77-81, May 23, 1977.

17. "Establishment of a Solar Energy Research Institute," Solar Energy Research Institute Cormittee Report, National Academy of Sciences, National Research Council, Sept. 1975, 3-49; "ERDA Selects SERI Contractor, Plans Regional Efforts," ERDA 77-57, March 24, 1977; "Solar Energy Research Institute: Grumbles About a Changes in Plans," Science, Vol. 196, April 15, 1977, 278-80.

18. ERDA-86, "Geothermal Energy Research, Development, and Demonstration Program," Oct. 1975.

19. "First ERDA Geothermal Resource Tapped in Idaho," ERDA 75-11, Feb. 7, 1975; "ERDA, San Diego Gas and Electric Sign Agreement on California Geothermal Experimental Facility," ERDA 75-173, Aug. 27, 1975; "Geothermal Test Facility Dedicated in California," ERDA 76-162, June 4, 1976.

20. ERDA-84, "Federal Wind Energy Program," Oct. 1975; "ERDA and NASA to Dedicate 100 KW Wind Turbine at Sandusky, Ohio," ERDA 75-206, Oct. 17, 1975; "ERDA, NASA Select Team to Build Largest Windmill in History," ERDA 76-255, Aug. 2, 1976; "ERDA Selects First Utility to Field-Test A 200 Kilowatt Wind Turbine Generator," ERDA 76-348, Nov. 23, 1976.

21. Report of the Field and Iaboratory Utilization Study Group, Dec. 1975, 14; Jack M. Holl, "The United States Department of Energy: A History," IODE, History Series, Vol I, No. 4, Sept. 1981.

22. Gerald R. Ford, "State of the Union Message," Jan. 5, 1975, SCEN Energy Documents, 203; "Federal Task Force's Final Report Recommends Synthetic Fuels Program" ERDA 76-17, Jan. 28, 1976; "ERDA Establishes Office of Commercialization," ERDA 76-33, Feb. 5, 1976. 
23. Memo: Roger W.A. LeGassie to Administrator, "Reorganization of the office of the Assistant Administrator for Planning, Analysis and Evaluation," Oct. 15, 1976; "ERDA Reassigns Functions of the Office of Commercialization," ERDA 76-340, Nov. 10, 1976; "Seamans Selects Illinois Site for \$237 Million Coal Demonstration Plant," ERDA 75-235, Nov. 17, 1975; "Conferees Back Energy Research Bill with Loan Guarantees," New York Times, Dec. 3, 1975.

24. "ERDA Makes Organizational Changes," ERDA 76-207, July 2, 1976.

25. Assistant Administrator for National Security to Administrator, April 16, 1976; Roger M. Anders, "The Office of Military Application," IODE History Series, Vol. 1, No. 1, Aug. 1980; "Funding and Management Alternatives for ERDA Military Application and Restricted Data Functions," ERDA 97, Jan. 1976; Section 307 (b), Energy Reorganization Act of 1974, as reprinted in Compilation of Energy-Related Legislation, published by the House Committee on Interstate and Foreign Commerce, Aug. 1979, 376. (Hereafter cited as HCIFC, Energy Legislation).

26. Report of the Field and Iaboratory Utilization Study Group, Dec. 1975; Memo: Administrator to Assistant Administrators: "Management Goals," Jan. 23, 1976; Paul H. O'Neill, Office of Management and Budget, to Dr. Robert C. Seamans, Jr., Oct. 7, 1976; James T. Lynn to Robert C. Seamans, Nov. 16, 1976; Staff Work Plan, Office of the Assistant Administrator for Field Operations, April 21, 1977.

27. "ERDA Assumes Management Responsibility for Clinch River Breeder Reactor Plant Project," ERDA 76-137, May 7, 1976; "Fact Sheet: Liquid Metal Fast Breeder Reactor Program," Feb. 1977; "Fact Sheet: Clinch River Breeder Reactor Plant Project," Feb. 1977.

28. The White House, "Statement by the President on Nuclear Policy," Oct. 28, 1976; Gerald R. Ford, "Message to Congress on Energy Legislation," Jan. 7, 1977; Jimmy Carter, "Statement on Decisions Following A Review of U.S. Nuclear Power Policy," April 7, 1977, SCEN Energy Documents, 351-364, 379-80; Richard G. Hewlett, "Federal Policy for the Disposal of Highly Radioactive Wastes from Commercial Nuclear Power Plants." March 9, 1978, unpublished mms, Historian's Office, Department of Energy, 29-38; "FRDA Administrator Announces Expanded Program in Management of ERDA, Commercial Nuclear Wastes," ERDA 76-46, Feb 19, 1976; "ERDA Studies Geologic Formations Throughout Nation for Data on Potential Site for Commercial Nuclear Waste Disposal," ERDA 76-355, Dec. 2, 1976.

29. ERDA 77-1, "A National Plan for Energy Research, Development and Demonstration," June $23,1977,2-8$.

30. Ibid., 45.

31. Department of Energy Organization Act, Aug. 4, 1977, as reprinted in HCIFC, Energy Legislation, 381-431; Roger M. Anders, "The Federal Energy Administration," IODE, History Series, Vol. 1, No. 3, Nov. 1980.

32. Jack M. Holl, "The United States Department of Energy: A History," IODE, History Series, Vol. 1, No. 4, Sept. 1981. 


\section{ENERCY RESEARCH AND DEVEIOPMENT ADMINISTRATION}

\section{ADMINISTRATOPS}

\section{Administrator}

Robert C. Seamans

December 1974 - January 1977

Robert W. Fri (Acting)

January 1977 - September 1977

Deputy Administrator

Robert W. Fri

March 1975 - September 1977

Assistant Administrators

Iraboratory and Field Coordination

Michael I. Yarymovych May 1975 - May 1977

David Israel

May 1977 - September 1977

Administration

Raymond G. Romatowski

January 1975 - December 1976

Robert F. Allnutt (Acting) December 1976 - September 1977

International Affairs

Nelson F. Sievering, Jr. February 1975 - September 1977

Planning and Analysis

Roger W. A. IeGassie February 1975 - September 1977

Fossil Energy

Philip C. White June 1975 - September 1977

Nuclear Energy

Richard W. Roberts June 1975 - February 1977

Robert D. Thorne (Acting) February 1977 - September 1977

Environment and Safety

James L. Liverman January 1975 - September 1977

Solar, Geothermal, and Advanced Energy Systems

John M. Team

Robert L. Hirsch

March 1975 - January 1976

March 1976 - March 1977

Donald A. Beattie (Acting) March 1977 - September 1977 
National Security

Alfred D. Starbird

May 1975 - September 1977

Conservation

Austin N. Heller

September 1975 - November 1976

G.G. Mannella (Acting)

November 1976 - September 1977

Institutional Relations

Eric H. Willis

July 1976 - September 1977

Controller

Merwyn C. Greer

January 1975 - September 1977

General Counsel

R. Tenney Johnson

James A. Wilderotter

February 1975 - April 1976

Hudson B. Ragan (Acting)

April 1976 - February 1977

February 1977 - September 1977 


\section{CHRONOLOGY}

Date

June 29, 1973

October 17, 1973

December 4, 1973

June 28,1974

October 11, 1974

October 26, 1974

December 31, 1974

January 19, 1975

February 7, 1975

June 28,1975

October 29, 1975

January 12, 1976
Event

President Nixon presents proposal to Congress for a Department of Energy and Natural Resources and an independent Energy Research and Development Administration.

Arab oil embargo declared.

Federal Energy Office established by President Nixon.

Federal Energy Office superseded by Federal Energy Administration.

President Ford signs Energy Reorganization Act of 1974, (PL 93-438), establishing the Energy Research and Development Administration, the Nuclear Regulatory Commission, and the Energy Resources Council.

Solar Energy Research, Development and Demonstration Act (PL 93-473) signed into law.

President Ford signs Federal Nonnuclear Energy Research and Development Act of 1974, (PL 93-577).

Official activation of Energy Research and Development Administration.

Drillers in southern Idaho tap first hot water resource in geothermal development program.

"Creating Energy Choices for the Future," ERDA's first national energy plan for research, development, and demonstration, presented to the President and Congress, (ERDA-48) .

ERDA's first prototype wind power system dedicated at Sandusky, Ohio.

ERDA announces first operation of Princeton Iarge Torus, largest tokomak fusion device in United States.

\section{Appendix II}


April 15, 1976

May 1976

June 4, 1976

November 23, 1976

March 24, 1977

April 7, 1977

April 29, 1977

June 23, 1977

July 5, 1977

August 4, 1977

October 1, 1977
"Creating Energy Choices for the Future," first annual update of ERDA's national energy plan for research, development, and demonstration, presented to the President and Congress, (ERDA-76-1).

ERDA assumes responsibility for management of the Clinch River Breeder Reactor (CRBR), the Nation's first large scale demonstration breeder reactor, in Oak Ridge, Tennessee.

Experimental 10 megawatt geothermal test loop facility dedicated at Niland, California.

Clayton, New Mexico selected as site for 200 kilowatt wind turbine.

Golden, Colorado selected as site for Solar Energy Research Institute (SERI), to be managed by Midwest Research Institute.

President Carter announces that the United States will defer indefinitely the reprocessing of spent fuel from civilian reactors, and delay the construction of the Clinch River Breeder Reactor.

President Carter's National Energy Plan submitted to Congress.

"A National Plan for Energy Research, Development and Demonstration" presented to the President and Congress, (ERDA-77-1).

Solar Energy Research Institute (SERI) begins operations.

President Carter signs the Energy Reorganization Act (PL 95-91), creating the Department of Energy.

Department of Energy activated. 


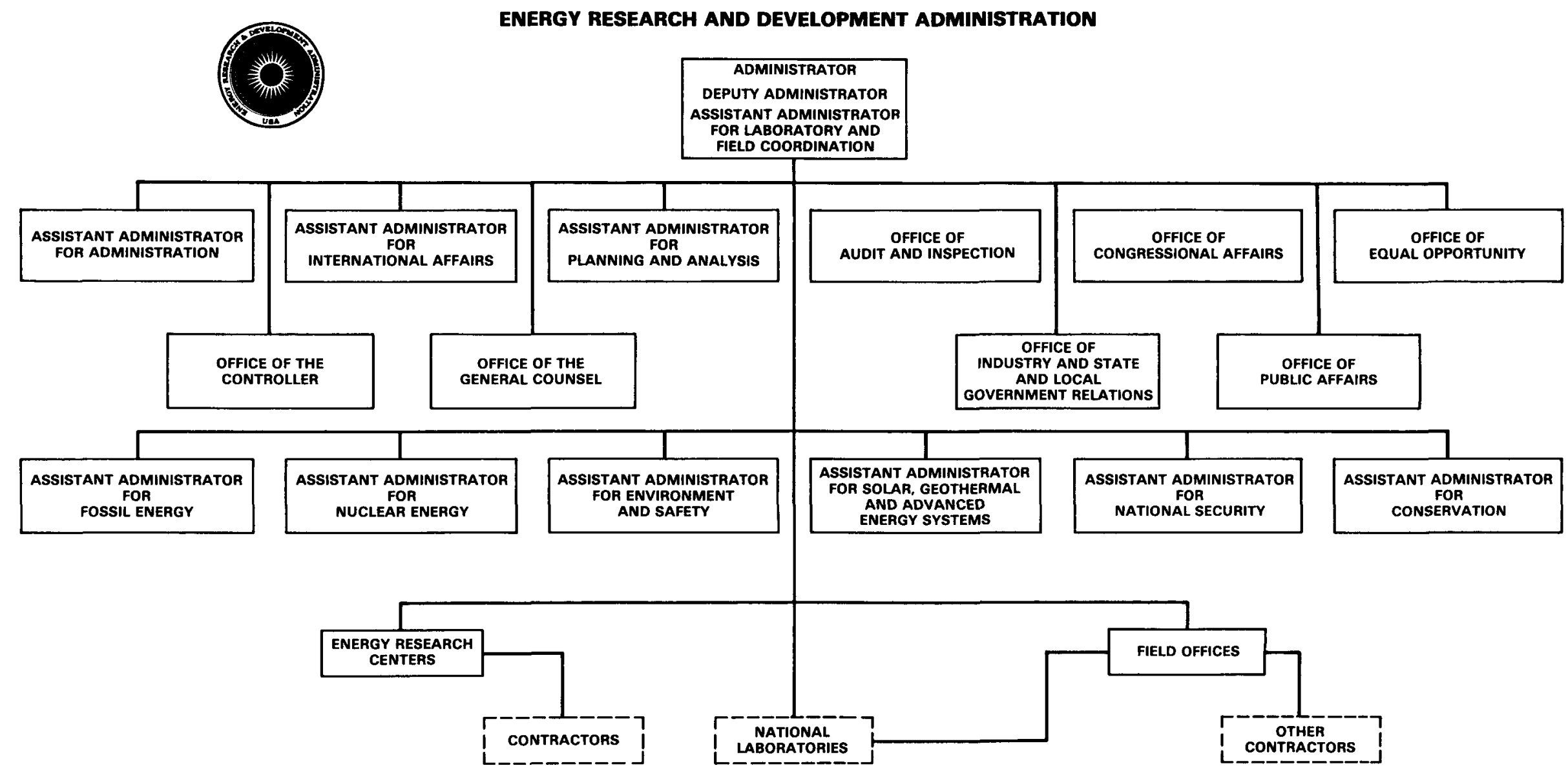




\section{ENERGY RESEARCH AND DEVELOPMENT ADMINISTRATION}
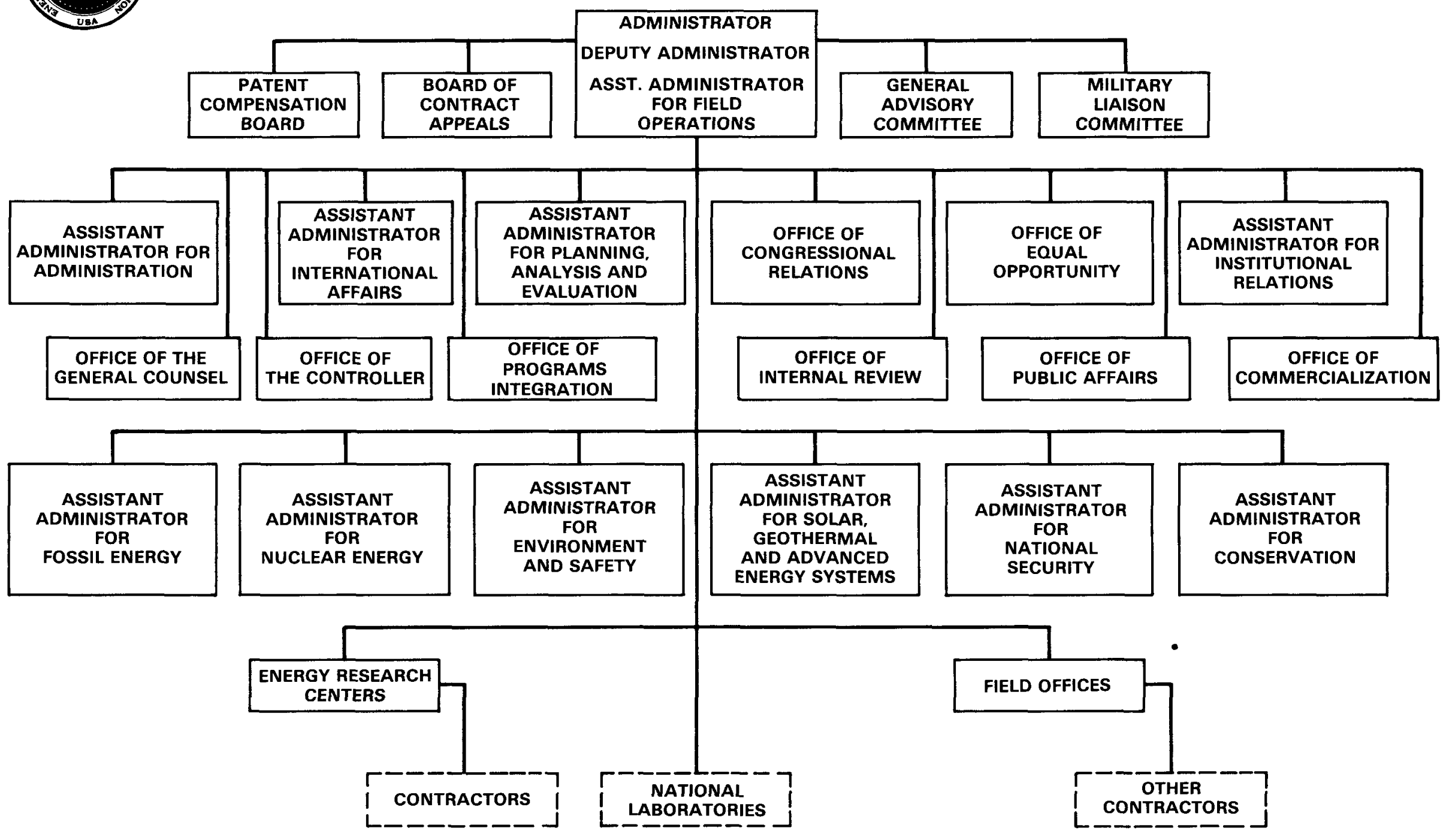
ENERGY RESEARCH AND DEVELOPMENT ADMINISTRATION

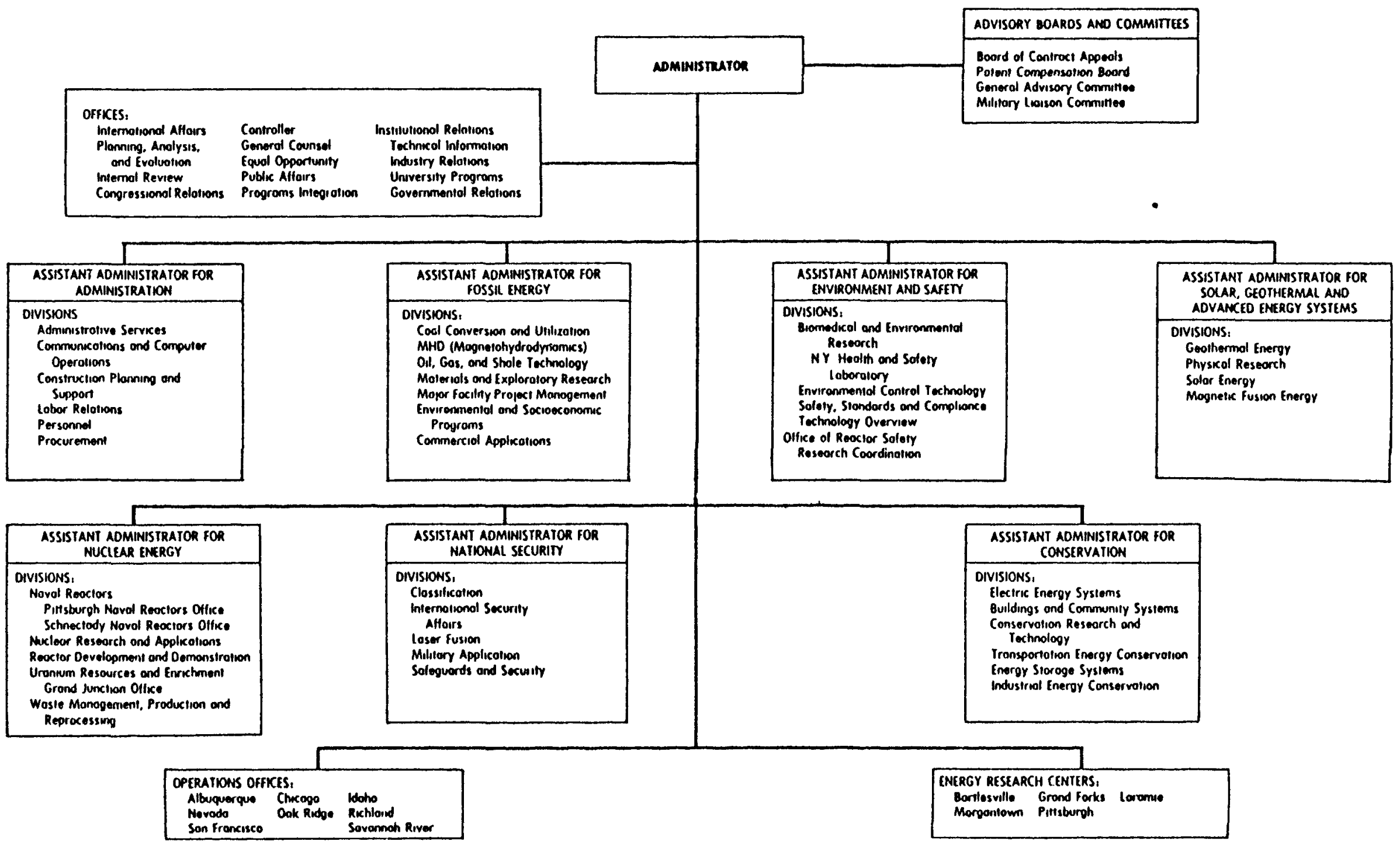

Offices and Divisions 


\section{ENERGY RESEARCH AND DEVELOPMENT ADMINISTRATION}

\section{FIELD FACILITIES}

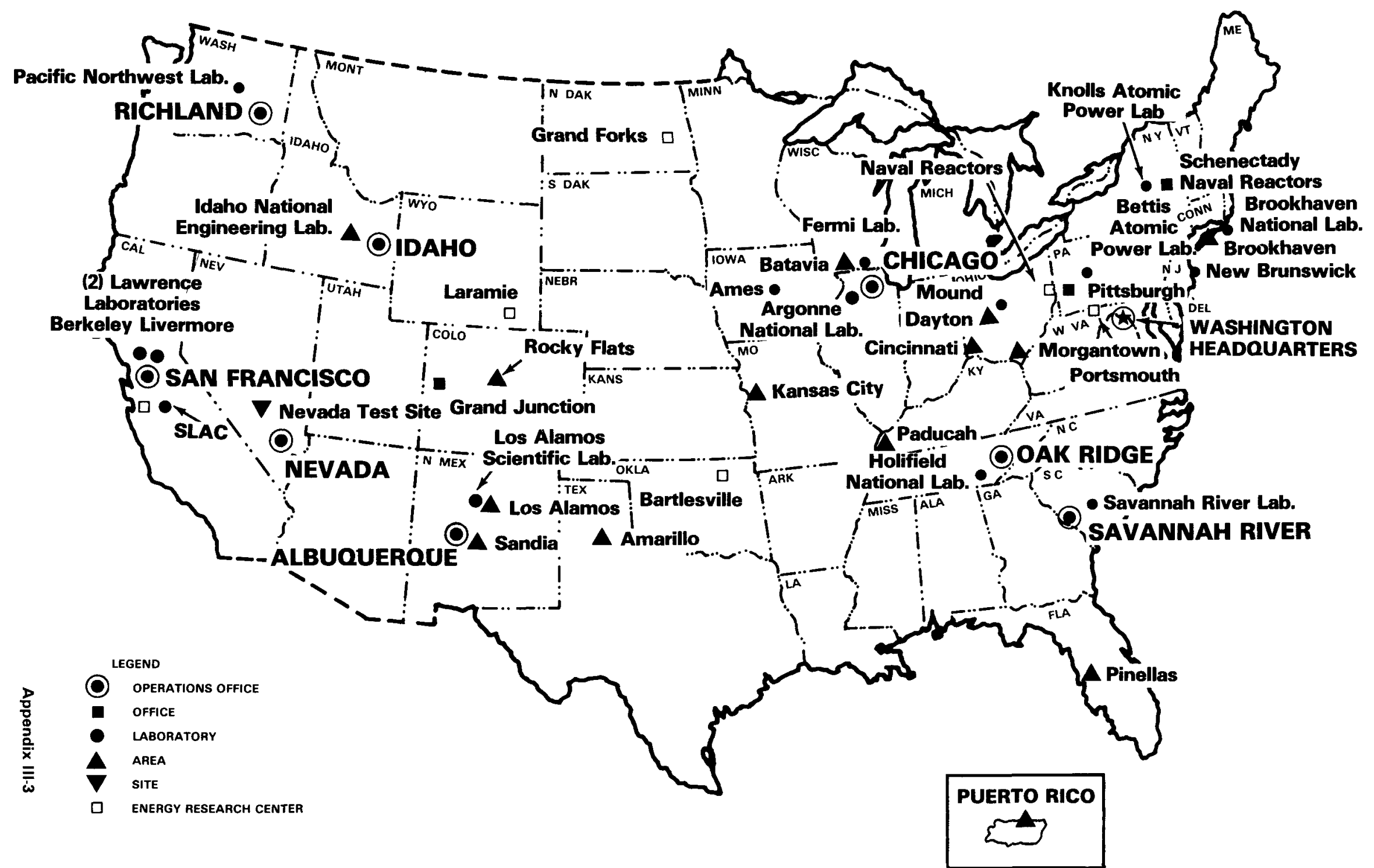

